\title{
Invasive pulmonary aspergillosis in a captive bird Cyanocompsa brissonii (Cardinalidae) in Mendoza, Argentina
}

\author{
Palma Leotta, M.; Pelegrina, M.; Cáceres, A. \\ Histopathology Service, Veterinary Practice Unit, Faculty of Veterinary and Environmental Sciences, \\ University Juan A. Maza. Av. Acceso Este, Lateral Sur 2245. Guaymallén, Mendoza, Argentina. \\ Postal Code 5519. Tel: 0054261-152074508 / 4056200. \\ E-mail:mae.leotta@gmail.com
}

\begin{abstract}
Palma Leotta, M.; Pelegrina, M.; Cáceres, A.: Invasive pulmonary aspergillosis in a captive bird Cyanocompsa brissonii (Cardinalidae) in Mendoza, Argentina. Rev. vet. 26: 1, 79-81, 2015. This report presents a case of invasive pulmonary aspergillosis in a captive bird Cyanocompsa brissonii ("ultramarine grosbeak"). The lesions observed suggest the infiltrative or superficial diffuse form of the disease, typical of the serosae and lungs. The infection and later death could be the outcome of a number of factors impairing the bird's immunity, and so predisposing to mycosis. The organism found was identified as Aspergillus fumigatus, based on the conidiophores characteristics, justifying the histopathological diagnosis of aspergillosis. From the epidemiological point of view, C. brissonii could be considered as potential reservoir of Aspergillus spp. when considering human disease. Moreover, when released back into the wild, it must be considered that disease introduction may have negatively impact on natural populations.
\end{abstract}

Key words: Cyanocompsa brissonii, Passeriformes, fungal infection, zoonotic vector.

\begin{abstract}
Resumen
Palma Leotta, M.; Pelegrina, M.; Cáceres, A.: Aspergillosis pulmonar invasiva en un pájaro cautivo (Cyanocompsa brissonii, Cardinalidae) en Mendoza, Argentina. Rev. vet. 26: 1, 79-81, 2015. Se reporta un caso de aspergillosis pulmonar en un ejemplar cautivo de Cyanocompsa brissonii ("reinamora grande"). Las lesiones observadas sugieren la forma infiltrativa o superficial difusa de la enfermedad, típica de las serosas y pulmones. El contagio y posterior muerte del animal podrían haber sido el resultado de una serie de factores que afectaron su inmunidad y predispusieron a la micosis. El organismo encontrado fue identificado como Aspergillus fumigatus, en base a la observación microscópica de conidióforos característicos. Desde el punto de vista epidemiológico, C. brissonii debería ser considerado como un reservorio potencial de Aspergillus spp. para la enfermedad humana. Por otra parte, al producirse la liberación de estas aves cautivas, debería considerarse el peligro de una eventual propagación de la micosis en las poblaciones silvestres.
\end{abstract}

Palabras clave: Cyanocompsa brissonii, Passeriformes, infección micótica, vector zoonótico.

\section{PRESENTATION}

A captive male "ultramarine grosbeak" (Cyanocompsa brissonii), approximately 7 years old, was submitted for necropsy to the Histopathology Service of the Veterinary Practice Unit (Faculty of Veterinary and Environmental Sciences, Juan A. Maza University, Argentina).

Recibido: 26 marzo 2015 / Aceptado: 14 abril 2015
The individual was house-kept as ornamental and song bird, and showed no evident signs or symptoms prior to death. Within six hours after death, the animal was preserved in $4 \%$ formalin until necropsy and histological examination were performed.

Considering the necropsy findings, portions from lungs and liver were collected. The samples were paraffin-embedded and four-micrometer-thick sections were obtained. After being dewaxed, sections were stained 
with hematoxylin-eosin for histopathological examination. Fungal formations were identified ${ }^{3,7}$.

\section{RESULTS}

Gross necropsy findings. The carcass was in good condition. Several diffuse, non-encapsulated, whitish spots were superficially scattered throughout the lungs and the parietal pleura. No lesions were observed in the upper respiratory tract or in other organs.

Histopathology. Microscopic examination of lung samples revealed generalized hyperemia, with hemorrhagic and emphysematous foci. Lost of epithelium lining and replacement with inflammatory exudate with abundant proteinaceus edema, fibrin and inflammatory cells (degenerate heterophils, plasmocites and macrophages) are observed in some secondary bronchi. This exudate extends was largely covering peripheral parenchyma and pleura. Eosinophilic necrotic foci with degenerated inflammatory cells were observed in the affected area (Figure 1). In bronchial lumen abundant fungal figures (hyphae, conidiophores and spores) were visualized, with hyphae invading the adjacent pulmonary parenchyma (Figures 1 and 2). Some dark-brown rounded shapes were scattered throughout the atrial wall of parabronchi, being also contained in macrophages (Figure 3).

Microscopic findings in the liver consisted of swollen hepatocytes, mild mononuclear inflammatory infiltrate in the portal tracts and hyperplasia in the bile ducts, with stratification of epithelia and presence of precursor cells. The capsule was observed with marked mononuclear inflammatory infiltrate, fibrin and edema.

Identification. Conidiophores showed close packed sterigmata parallel to the longer axis and bottle-shaped heads, which justify the identification as Aspergillus fumigatus. The brown pigmented shapes suggest the concomitant presence of dematiaceous moulds.

\section{DISCUSSION}

The macroscopic and microscopic lesions observed in lungs suggest the infiltrative or superficial diffuse form of the disease, typical of the serosae and lungs ${ }^{2,8}$. In aerated organs, with the absence of a structured granuloma formation, and in presence of atmospheric oxygen, the fungus may form aggregates of hyphaes containing conidiophores and conidia, which are known to be tissue-invasive, and thus explaining the invasion observed in lung parenchyma ${ }^{1}$. Furthermore, the microscopic changes diagnosed in liver, are compatible with the presence of aflatoxins in the diet.

The animal disease and death can be interpreted as the outcome of a number of factors impairing the bird's immunity, and so predisposing to mycosis ${ }^{1}$. The animal showed no evident symptoms prior to death and there is no reliable information about predisposing fac-

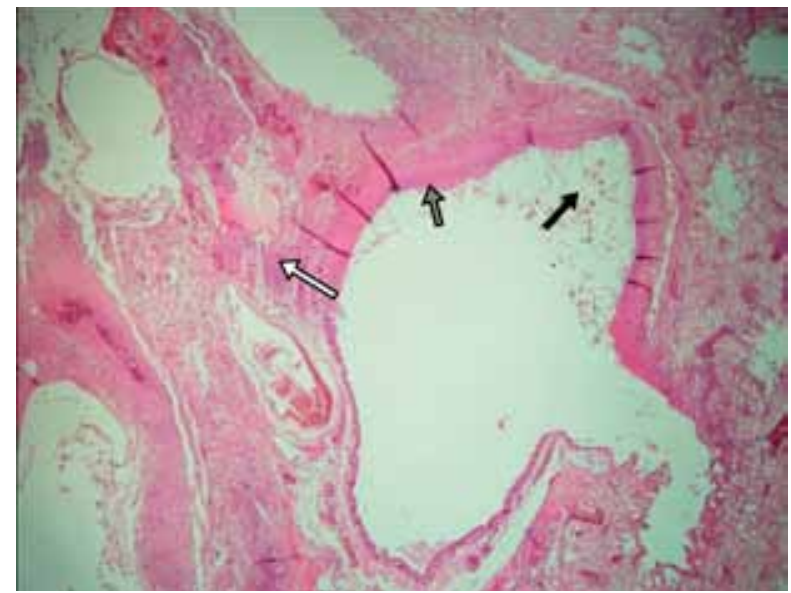

Figure 1. Tissue section from the lung of the "ultramarine grosbeak", focal tissue necrosis and diffuse inflammation (white arrows), lost of epithelium lining (dark grey arrow), and fungal figures in lumen (black arrow). H\&E 100x.

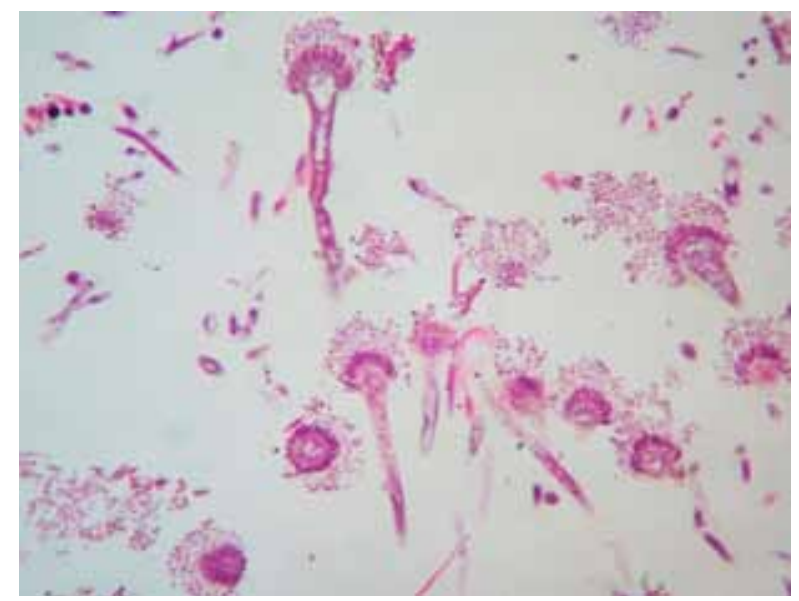

Figure 2. Fungal figures in bronchial lumen, identified as Aspergillus fumigatus. H\&E 400x.

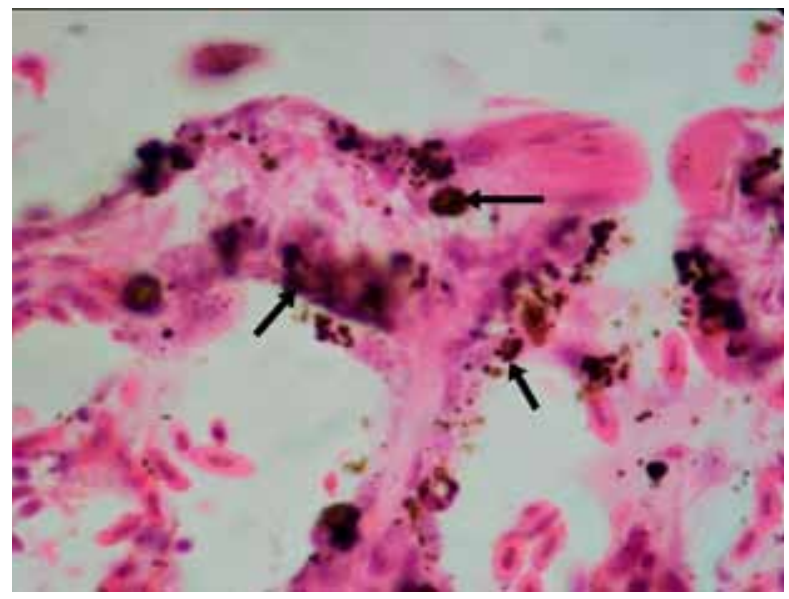

Figure 3. Brown pigmented shapes in parabronchus, suggesting concomitant presence of dematiaceous moulds (black arrows). H\&E 1000x.

tors but reproductive activity, so no plausible causes could be discussed ${ }^{1}$. Many birds can host the spores of Aspergillus spp. in lungs and air sacs, leading to a dor- 
mant or chronic infection, with no clinical symptoms or apparent anatomopathological lesions ${ }^{8}$.

The single observation of typical conidiophores in microscopic lesions justifies the histopathological diagnosis of aspergillosis, still in absence of fungal culture or immunological tests ${ }^{10}$. As mentioned, the organism was identified as $A$. fumigatus, based on the conidiophores characteristics. The reason why A. fumigatus is the predominant species of airborne fungal infection might be that the spores are much smaller than the spores of other Aspergillus species, and thus are not completely trapped in nasal cavity or trachea, being able to reach the lungs and air sacs ${ }^{1}$.

Despite being not frequent in mammals, invasive aspergillosis is considered a life-threatening zoonoses, usually occurring in immunocompromised patients ${ }^{9}$. As consequence of immunosuppressive regimens in the transplant recipients, aggressive anti-cancer chemotherapy and the HIV/AIDS pandemic, invasive aspergillosis incidence has markedly increased in the past two decades, with mortality rates in proven infections ranging from $60-90 \%$, and so constituting a severe public health risk ${ }^{6}$. Furthermore, the occurrence of chronic invasive aspergillus in immunocompetent patients had also been suggested ${ }^{5}$.

To our knowledge, this is the first histopathological description of aspergillosis in "ultramarine grosbeak". In light of the previously exposed, the increasing amount of immunosuppressed patients, and its frequent possession as song/ornamental bird, the species should be considered a potential reservoir of Aspergillus spp. Moreover, when released back into the wild as part of re-introduction programs of confiscated fauna, it must be considered that the species may introduce the fungi and negatively impact natural populations ${ }^{4}$.

Acknowledgements. We thank Rômulo Alves, Daniel González Acuña and Silvia Neri Godoy for the bibliography provided; Roberto Mera y Sierra for the critical reading, Pablo Cuervo and Jorge Ledesma for helping in the translation. Study funded by Ciencia y Técnica, Universidad Juan A. Maza, Mendoza, Argentina.

\section{REFERENCES}

1. Beernaert LA, Pasmans F, Van Waeyenberghe L, Haesebrouck F, Martel A. 2010. Aspergillus infection in birds: a review. Avian Pathol 39: 325-331.

2. Cacciuttolo E, Rossi G, Nardoni S, Legrottaglie R, Mani P. 2009. Anatomopathological aspects of avian aspergillosis. Vet Res Commun 33: 521-527.

3. Cutsem JV, Rochette F. 1991. Poultry. In: Mycoses in domestic animals (Cutsem JV, Rochette F, Eds), Janssen Research Foundation, Beerse (Belgium), p.111-126.

4. Godoy SN, Matushima ER. 2010. A survey of diseases in passeriform birds obtained from illegal wildlife trade in São Paulo city, Brazil. J Avian Med Surg 24: 199-209.

5. Karim A, Alam M, Shah AA, Ahmed R, Sheikh H. 1997. Chronic invasive aspergillosis in apparently immunocompetent hosts. Clin Infect Dis 24: 723-733.

6. Lin SJ, Schranz J, Teutsch SM. 2001. Aspergillosis casefatality rate: Systematic review of the literature. Clin Infect Dis 32: 358-366.

7. McClenny N. 2005. Laboratory detection and identification of Aspergillus species by microscopic observation and culture: the traditional approach. Med Mycol (Suppl.1) 43: S125-S128.

8. Nardoni S, Ceccherelli R, Rossi G, Mancianti F. 2006. Aspergillosis in Laruscachinans micaellis: Survey of eight cases. Mycopathologia 161: 317-321.

9. Tekaia F, Latgé JP. 2005. Aspergillus fumigatus: saprophyte or pathogen? Curr Opin Microbiol 8: 385-392.

10. Watts JC, Chandler FW. 1997. Aspergillosis. In: Pathology of Infectious Diseases (Connor DH, Ed.), Appleton \& Lange, Stamford (USA), p. 933-940. 
